\title{
INTERNET SOURCES
}

\section{Sources of Militaria on the World Wide Web}

\author{
KIM WALKER \\ Assistant Librarian, National Monuments Council
}

Having an interest in military-type topics is one thing, finding information on the web to quench your thirst for knowledge is another. The World Wide Web (WWW) is a universal electronic library that contains millions of web pages. As well as being fun, it is an addictive tool on which to search for information. To prevent hours of useless wandering around the WWW, the following sources of general information have been compiled on military institutions, museums and battlefields for the military enthusiast out in cyberspace. Please be warned that sites are prone to move once in a while or are still under construction and this could cause difficulty in accessing them.

\section{GENERAL SOURCES}

First to be discussed is Armour on Display: List of Military Museums created by Claus Bonnesen of Danmark (sic) which lists museums of the following countries, Belgium, Canada, Danmark (sic), England, Finland, France, Germany, Holland, Luxembourg, New Zealand, Russia, Schweiz (Switzerland), Sweden, and the USA. The URL (the Uniform Resource Locator - a unique address for each page of information on the WWW) is <http:/ /www.cybernet.dk/USERS/C_BONNESEN/OAMUSLST.HTM>.

The Royal Military Academy of Belgium has a home page which, amongst other things, has links to a military museum, the academy library and the various academy teaching departments. From this site there are links to: the United States Military Academy (West Point), Ecole Polytechnique (Plasaiseau), the Royal Military College of Canada, the Australian Defence Force Academy, the US Coast Guard Academy and the US Air Force. The home page URL is $<\mathrm{http}: / /$ www.rma.ac.be/>. Be warned that there are lots of graphics to download which will take some time and patience.

There is a general War and Military Resources on the Web site at <http:// 
cougarnet.byu.edu/acd1/fhsswww/html/departmt/history/civlmili.htm $>$ which lists sites under the titles of: Civil War, military history, and World War II.

The National Park Service (NPS) of the USA has a home page on the web and links to the Civil War. Addresses to these links are: a general table of contents is to found at $<$ http://www.cr.nps.gov/colherit.htm>, the Civil War Sites Advisory Commission Report on the Nation's Civil War Battlefields is at <http://www2.cr.nps.gov/abpp/cws0-1.html > and the history of the African-Americans in the Civil War is to be found at $<$ http:www.itd.nps.gov/cwss/africanh.html>. The NPS is also very involved in conservation of battlefields, information on the Treatment Approaches for Historic Battlefield Landscapes is at $<\mathrm{http} / /$ www2.cr.nps.gov/abpp/sp97six.htm $>$ and the table of contents of the Battlefield Update: Newsletter of the American Battlefield Protection Program is at $<\mathrm{http}$ // /www2.cr.nps.gov/abpp/bu past/w97toc.htm>, issue 62 of the summer of 1996 contains a useful article entitled: Battlefields and the World Wide Web, which supplies URLs for conservation bodies as well as general information on things Confederate, an index of Civil War discussion groups, war diaries, letters, museums and much more.

\section{THE ANGLO-BOER WAR ON THE WEB}

The Anglo-Boer War is of interest these days as its centenary is approaching. The following sites containing references to the war have been put on the web by military enthusiasts, academic scholars or tourist companies. The item that I found was an article entitled Anglo-Boer War Set the Stage for Military Wireless Telegraphy by Duncan C Baker an IEEE senior member of TInet in Pretoria. The article appeared in the Institute of Electrical and Electronics Engineers' (IEEE) publication Institute in August 1995. It can be found at <http://www.institute.ieee.org/INST/aug95/wireless.html>. The URL of IEEE is $<$ http://www.ieee.org/>.

The South African Communication Service (SACS) at <http://www.sacs.org.za/ $>$ contains some general information in the form of chapters on South African history at $<\mathrm{http}$ :/ /www.sacs.org.za/level2/history.htm>.

ATT Heritage Tours has a URL at <http://atex.co.za/att/heritage/> and advertises various tours of battlefields in South Africa. Short descriptions of the First Anglo-Boer War (1880-1881) and South African War (1899-1902) can be found at their site at <://atex.co.za/ att/heritage/history.html $>$. The other various tours are listed at $<$ http://atez.co.za/att/heritage/content.html>.

The most informative site found was the South African War Virtual Library home page situated at $<$ http://www.uq.edu.au/ Zzrwotto/contents.html>; it is interesting to note that the site is maintained by the University of Queensland in Australia and is also available in Afrikaans. There is a contents page which allows one access to: a chronology of the war; a short history of the war; biographies of major figures; statistics of the war; the Boer forces; British/Commonwealth forces; the volunteers; the battles of the war; Africans and 
the war; the camps; foreign political involvement; the weaponry; maps of battles; images from the war; a C R de Wet page; links to related sites; and a bibliography of works on the war..

The League of Researchers of South African Battlefields have a home page at $<$ http:/ /www.icon.co.za/ dup42/Welcome.html>, they have a page dedicated to the Anglo-Boer War Centenary Celebrations at <http://www.icon.co.za/ dup42/war.htm> which supplies a short summary of the war; foreign regiments involved in the war; Anglo-Boer War related literature; a list of military and Anglo-Boer War related museums; an Anglo-Boer War discussion page; and a site entitled Sources Where by the Blow-by-Blow Events of Each Battle and Every Skirmish of the Anglo-Boer War can be Traced.

The University of Stellenbosch maintains the Anglo-Boer War Web Archive at <http:/ /lib.sun.ac.za/army/AngloBoerWar/>. This site contains a list of books on the war available at the library of the University of Stellenbosch, various other lists of related books, research interests, e.g. Boer War Railways: Colonel Camilla Richiardi; and Boer War Trains: De Wet is the Station Master, which contain e-mailed information on the topics.

The Information Resource Centre of the Canadian Forces College of the Department of National Defence (Canada) has a URL at <http://www.cfcsc.dnd.ca/links/milhist/> which lists military history by periods and which has a reference to the Boer Wars (1880-1881, 1899-1902).

Copyrighted to America Online is a URL entitled Centenary $2^{\text {nd }}$ Anglo-Boer War which is a listserv enabling one to subscribe to a list of discussion on the Second Anglo-Boer War (1899-1902) maintained by Marius Swart. It can be found at <http://ifrit.web.aol.com/ $\mathrm{mld} /$ production/yiaz1615.html>. 